\title{
Status Gizi Ibu dan Persepsi Ketidakcukupan Air Susu Ibu
}

\author{
Maternal Nutritional Status and Breast Milk Insufficiency Perception
}

\author{
Sandra Fikawati, Ahmad Syafiq
}

Pusat Kajian Gizi dan Kesehatan Fakultas Kesehatan Masyarakat Universitas Indonesia

\begin{abstract}
Abstrak
Menyusui eksklusif kurang dari 6 bulan berkontribusi terhadap 1,4 juta kematian bayi dan $10 \%$ angka kesakitan balita. Persepsi Ketidakcukupan Air Susu lbu (PKA) yang memengaruhi kepercayaan diri untuk menyusui menjadi salah satu penyebab utama kegagalan pemberian air susu ibu (ASI) eksklusif di dunia. Salah satu faktor penyebab PKA adalah ketidakmampuan ibu hamil untuk mencapai kenaikan berat badan (BB) yang direkomendasikan sehingga ibu berisiko melahirkan bayi berat lahir rendah (BBLR) dan memiliki cadangan lemak rendah untuk memproduksi ASI. Penelitian ini bertujuan untuk mengetahui hubungan antara status gizi ibu dan PKA. Penelitian ini merupakan kajian terhadap 3 studi yang menganalisis di Kabupaten Karawang, Kecamatan Cilandak, dan Kecamatan Tanjung Priok pada tahun 2010 dan 2011. Hasil penelitian menunjukkan hubungan yang bermakna antara status gizi ibu dan PKA dengan odds ratio (OR) masing-masing 3,7 (1,470 - 9,081); 3,9 (1,551 - 9,832); dan 4,5 $(1,860$ - 11,008). Disimpulkan bahwa PKA dialami oleh ibu menyusui yang selama hamil tidak mencapai kenaikan BB yang direkomendasikan menyebabkan ibu berhenti memberikan ASI eksklusif. Penemuan yang penting ini dapat digunakan untuk mengubah anggapan para pakar ASI dan masyarakat bahwa semua ibu, apapun kondisi status gizinya, mampu menyusui ekslusif. Penelitian ini diharapkan menjadi masukan bagi penentu kebijakan untuk memerhatikan status gizi ibu menyusui.

Kata kunci: Status gizi ibu, persepsi ketidakcukupan ASI, ASI eksklusif
\end{abstract}

\section{Abstract}

Exclusive breastfeeding for less than 6 months contributed to the 1,4 million deaths of infants and $10 \%$ toddlers' morbidity. Perceived Insufficient Milk (PIM) became one of the main causes of exclusive breastfeeding failure in the world. PIM could occured by inability of pregnant women to achieve the recommended weight gain thus mothers have the risk of giving birth of low birth weight (LBW) infants and have low fat reserves to produce milk. Low production of breast milk will negatively affect the confidence of mothers to breastfeed. This study aimed to examine three studies that analyzed the relationship between maternal nutritional status and PIM. The study was conducted in three places Karawang district, Tanjung Priok subdistrict, and Cilandak sub district in 2010 and 2011. The results of this study showed significant associations between maternal nutritional status and PIM with odds ratio (OR) $3,7(1,47$ to 9,08$) ; 3,9(1,55$ to 9,83$)$; and $4,5(1,86$ to 11,01$)$ respectively. It concluded that PIM was experienced by breastfeeding mothers whose maternal weight gain during pregnancy did not achieve the recommendation and caused the mother to stop exclusive breastfeeding. This discovery is important and useful to change the existing perception among breastfeeding experts and communities all mothers, regardless their nutritional status, are able to breastfeed exclusively. The study is expected to provide input for policy makers to pay more attention to the nutritional status of breastfeeding mothers.

Key words: Maternal nutritional status, perceived insufficient milk, exclusive breastfeeding

\section{Pendahuluan}

Pola menyusui tidak optimal yang memberikan air susu ibu (ASI) eksklusif kurang dari 6 bulan diperkirakan berkontribusi terhadap 1,4 juta kematian bayi dan 10\% angka kesakitan balita. ${ }^{1}$ World Health Organization (WHO) menyarankan agar ibu memberikan ASI eksklusif kepada bayi sampai 6 bulan. ${ }^{2}$ Kementerian Kesehatan Republik Indonesia melalui Kepmenkes RI No. 450/Menkes/SK/IV/Tahun 2004 tentang Pemberian ASI secara eksklusif pada bayi di Indonesia menetapkan pemberian ASI eksklusif selama 6 bulan dan menarget-

Alamat Korespondensi: Sandra Fikawati, Pusat Kajian dan Kesehatan FKM Universitas Indonesia, Gd. F Lt. 2 Kampus Baru UI Depok 16424,

Hp.08161867813,e-mail: sandrafikawati@yahoo.com 
kan cakupan ASI eksklusif sebesar 80\%. Namun sudah hampir 1 dasawarsa, target tersebut tetap jauh dari capaian. Berbagai penelitian di Indonesia melaporkan persentase ASI eksklusif 6 bulan masih di bawah 20\%.36

Alasan terbanyak ibu menghentikan pemberian ASI eksklusif karena merasa ASI-nya tidak mencukupi kebutuhan bayi. Sekitar 35\% ibu menghentikan pemberian ASI secara eksklusif pada beberapa minggu post partum karena merasa ASI kurang dan bayi merasa tidak puas. ${ }^{2}$ Penelitian Tjekyan, ${ }^{7}$ terhadap 845 bayi di Jakarta menunjukkan bahwa alasan terbesar kegagalan ASI eksklusif karena ibu mengeluh ASI sedikit (32\%). Hasil penelitian Chan et al, ${ }^{8}$ di Hongkong menunjukkan penyebab terbesar (44\%) ibu memberikan susu formula pada bayi umur 2 dan 6 minggu post partum serta pada bayi umur 3 dan 6 bulan post partum karena persepsi kekurangan suplai ASI kemudian sebab mempunyai masalah payudara (31\%) dan kelelahan (28\%).

Gatti, ${ }^{9}$ melaporkan bahwa Persepsi Ketidakcukupan ASI (PKA) menjadi salah satu penyebab utama kegagalan pemberian ASI eksklusif di dunia. Namun, saat ini belum diketahui apakah persepsi ini bersifat fisiologis atau psikologis. Robbin dalam Notoatmodjo, ${ }^{10}$ mendefinisikan persepsi sebagai proses seseorang mengorganisasikan dan menginterprestasikan sensasi yang dirasakan untuk memberi makna terhadap lingkungannya. Dengan demikian, persepsi adalah suatu proses otomatis yang terjadi dengan sangat cepat dan kadang tidak disadari ketika dapat mengenali stimulus yang diterima. ${ }^{10}$ Dalam mengenali apakah PKA bersifat fisiologis atau psikologis perlu diketahui penyebab dari PKA. Bila PKA tidak didasarkan penyebab yang jelas maka kemungkinan besar PKA bersifat psikologis. Namun, jika PKA berhubungan dengan penyebab fisiologis misalnya kekurangan gizi maka PKA dapat dianggap sebagai satu rangkaian antara masalah fisiologis dan psikologis.

Data Riset Kesehatan Dasar (Riskesdas) tahun 2010 menyebutkan indeks massa tubuh (IMT) rendah banyak dijumpai pada kelompok wanita usia $18-24$ tahun $(24,8 \%)$ diikuti oleh kelompok usia 25 - 29 tahun $(15,8 \%) .3$ Studi de Pee et al, ${ }^{11}$ menunjukkan hasil yang serupa bahwa masalah IMT rendah (sekitar 20\%) terjadi pada usia muda. Studi dilakukan di daerah kumuh perkotaan. Di wilayah pedesaan, Irawati, 12 menemukan bahwa 9\% - 21\% wanita usia subur memiliki IMT yang rendah. IMT ibu merupakan indikator status gizi ibu menyusui karena IMT ibu menunjukkan simpanan lemak ibu yang akan digunakan untuk menyusui. Institute of Medicine (IOM) merekomendasikan kenaikan berat badan (BB) hamil yang lebih besar $(12,5 \mathrm{~kg}-18 \mathrm{~kg})$ pada ibu dengan IMT rendah $(<18,5)$ dibandingkan untuk ibu dengan IMT sedang $(18,5$ - 24,99) sebesar $11,5 \mathrm{~kg}-$ $16 \mathrm{~kg}$, IMT tinggi (> 25) sebesar $7 \mathrm{~kg}-11,5 \mathrm{~kg}$, dan IMT obesitas (> 30) sebesar $5 \mathrm{~kg}-9 \mathrm{~kg} .{ }^{13}$

Penelitian Irawati, 12 di Indonesia menunjukkan bahwa status gizi ibu pada masa laktasi berpengaruh terhadap keberhasilan menyusui, ibu yang kurang gizi berisiko tidak berhasil menyusui 2,26 - 2,56 kali lebih besar dibandingkan ibu dengan gizi baik. Hasil studi secara konsisten menunjukkan bahwa ibu hamil yang dapat memenuhi rekomendasi IOM tersebut menghasilkan outcome kehamilan yang baik yaitu bayi lahir dengan berat normal (sekitar $3 \mathrm{~kg}$ ) dan mempunyai cadangan lemak yang cukup. ${ }^{13}$ Ibu hamil dengan kenaikan BB lebih rendah dari BB yang direkomendasikan mempunyai cadangan lemak rendah. Hal ini secara negatif akan memengaruhi kemampuan ibu memproduksi ASI.

Saat ini di Indonesia, informasi mengenai PKA masih sangat terbatas. Penelitian untuk mengetahui apakah ada hubungan antara status gizi ibu saat hamil dan menyusui dengan PKA sangat diperlukan. Penelitian ini bertujuan untuk mengkaji 3 studi yang menganalisis hubungan antara status gizi ibu dan PKA. Salah satu faktor penyebab terjadinya PKA diduga adalah ketidakmampuan ibu hamil untuk mencapai kenaikan BB yang direkomendasikan oleh IOM sehingga ibu berisiko melahirkan bayi berat lahir rendah (BBLR) dan mempunyai cadangan lemak yang rendah untuk memproduksi ASI. ${ }^{13}$

Cadangan lemak yang disimpan selama hamil merupakan modal dasar tubuh ibu untuk memproduksi ASI. Bila status gizi ibu kurang atau ibu hamil memiliki kenaikan BB yang kurang dari rekomendasi IOM maka hal terbesar yang akan dikorbankan adalah cadangan lemak ibu. ${ }^{13}$ Cadangan lemak ibu dengan status gizi baik terlihat lebih banyak dibandingkan ibu dengan status gizi kurang, sementara produk kehamilan meliputi janin, plasenta, dan cairan amnion tidak berbeda.

Apabila kenaikan BB ibu kurang dari rekomendasi IOM dan cadangan lemak ibu untuk menyusui rendah maka kemampuan ibu memproduksi ASI juga berkurang sehingga ibu akan merasakan bahwa ASI yang dikeluarkan hanya sedikit. ASI yang kurang akan memengaruhi kepercayaan diri ibu untuk menyusui sehingga menyebabkan terjadinya PKA yang selanjutnya memengaruhi pikiran ibu dan pengeluaran hormon oksitosin. Gangguan pada hormon oksitosin akan menyebabkan gangguan pada kontraksi otot payudara sehingga pengeluaran ASI terhambat. Di sisi lain, karena pengeluaran ASI berkurang, ibu semakin jarang menyusui sehingga memengaruhi pengeluaran hormon prolaktin yang akan menyebabkan produksi ASI semakin berkurang. Penelitian ini bertujuan untuk mengetahui hubungan antara status gizi ibu dengan PKA.

\section{Metode}

Penelitian ini merupakan kajian 3 studi yang di- 
Tabel 1. Deskripsi Studi dalam Kajian

\begin{tabular}{|c|c|c|c|}
\hline Lokasi & Populasi & Sampel & Waktu Studi \\
\hline Kabupaten Karawang & $\begin{array}{l}\text { Seluruh ibu bayi usia }>6-12 \text { bulan } \\
\text { yang datang ke } 5 \text { Puskesmas PONED } \\
\text { di wilayah Kabupaten Karawang } \\
\text { untuk mendapatkan imunisasi }\end{array}$ & $87 \mathrm{ibu}$ & Maret-April 2010 \\
\hline Kecamatan Tanjung Priok & $\begin{array}{l}\text { Seluruh ibu bayi usia }>6-12 \text { bulan } \\
\text { yang datang ke Puskesmas Kecamatan } \\
\text { Tanjung Priok Jakarta Utara } \\
\text { untuk mendapatkan imunisasi }\end{array}$ & $100 \mathrm{ibu}$ & Maret-Mei 2011 \\
\hline Kecamatan Cilandak & $\begin{array}{l}\text { Seluruh ibu bayi usia }>6-12 \text { bulan } \\
\text { yang datang ke Puskesmas Kecamatan } \\
\text { Cilandak Jakarta Selatan untuk mendapatkan } \\
\text { imunisasi dan pemeriksaan MTBS }\end{array}$ & $100 \mathrm{ibu}$ & Maret-Mei 2011 \\
\hline
\end{tabular}

Tabel 2. Prevalensi PKA di 3 Studi Tahun 2010-2011

\begin{tabular}{|c|c|c|c|c|c|c|}
\hline \multirow[t]{2}{*}{ PKA } & \multicolumn{2}{|c|}{$\begin{array}{l}\text { Wilayah Puskesmas PONED } \\
\text { Kabupaten Karawang }\end{array}$} & \multicolumn{2}{|c|}{$\begin{array}{c}\text { Wilayah Puskesmas } \\
\text { Kecamatan Tanjung Priok }\end{array}$} & \multicolumn{2}{|c|}{$\begin{array}{l}\text { Wilayah Puskesmas } \\
\text { Kecamatan Cilandak }\end{array}$} \\
\hline & $\mathbf{n}$ & $\%$ & n & $\%$ & $\mathbf{n}$ & $\%$ \\
\hline Ya & 36 & 41,4 & 32 & 32,0 & 37 & 37,0 \\
\hline Tidak & 51 & 58,6 & 68 & 68,0 & 63 & 63,0 \\
\hline Total & 100,0 & 100,0 & 100,0 & 100,0 & 100,0 & 100,0 \\
\hline
\end{tabular}

lakukan secara kuantitatif menggunakan data primer dan sekunder dengan desain cross sectional yang dilakukan di 3 daerah yang berbeda yaitu Kabupaten Karawang, Kecamatan Tanjung Priok, dan Kecamatan Cilandak (Tabel 1). ${ }^{14-16}$ Kriteria inklusi yang ditetapkan oleh 3 studi adalah mempunyai data ibu yang menyangkut tinggi badan (TB) dan 2 data BB pada masa hamil dengan selang pengukuran 11 minggu. PKA adalah keadaan seorang ibu telah atau menganggap dirinya tidak lagi memiliki ketersediaan ASI yang cukup untuk memenuhi kebutuhan bayinya yang diukur melalui wawancara. PKA dianggap terjadi apabila ibu berhenti menyusui secara eksklusif dengan alasan tidak ada ASI, ASI kurang atau ASI tidak mencukupi, sedangkan PKA tidak terjadi bila ibu berhenti menyusui secara eksklusif dengan alasan lain yang tidak terkait dengan tidak ada ASI, ASI kurang atau ASI tidak mencukupi.

Status gizi ibu hamil diukur berdasarkan estimasi IMT prahamil dengan kenaikan BB yang dicapai selama hamil. Status gizi ibu dianggap kurang apabila kenaikan BB ibu kurang dari rekomendasi IOM yaitu bila IMT < 18,5 dengan penambahan $\mathrm{BB}<12 \mathrm{~kg}$; IMT 18,5 - 24,9 dengan penambahan $\mathrm{BB}<11 \mathrm{~kg}$; IMT $>25$ dengan penambahan $\mathrm{BB}<6 \mathrm{~kg}$. Status gizi baik bila kenaikan $\mathrm{BB}$ hamil sesuai rekomendasi yaitu IMT $<18,5$ dengan penambahan BB $12 \mathrm{~kg}$ - $18 \mathrm{~kg}$; IMT 18,5 - 24,9 dengan penambahan BB $11-15 \mathrm{~kg}$; IMT > 25 dengan penambahan BB $6 \mathrm{~kg}-11 \mathrm{~kg}$.

\section{Hasil}

Prevalensi PKA pada 3 studi yang dikaji terlihat tinggi di atas 30\%, masing masing di Kabupaten Karawang $(41,4 \%)$, Kecamatan Tanjung Priok $(32,0 \%)$, dan Kecamatan Cilandak (37,0\%) (Tabel 2).

Status gizi ibu diukur melalui IMT prahamil dan kenaikan BB ibu selama hamil sesuai dengan rekomendasi IOM. ${ }^{13}$ Proporsi ibu yang mengalami kenaikan BB selama hamil tidak sesuai dengan kenaikan BB yang direkomendasikan IOM juga tinggi, sekitar 40\%. Bahkan di wilayah Kecamatan Tanjung Priok mencapai 45\% (Tabel 3).

Analisis bivariat dilakukan untuk melihat hubungan antara kenaikan BB ibu dan PKA. Hasil analisis menunjukkan hubungan yang signifikan antara kenaikan BB ibu dan PKA pada 3 studi tersebut. Tabel 4 menunjukkan hubungan antara kenaikan BB ibu hamil dan PKA.

\section{Pembahasan}

Prevalensi PKA di setiap wilayah tergolong tinggi. Di Kabupaten Karawang, PKA mencapai 41,4\% berarti ibu yang menghentikan ASI eksklusif karena merasa produksi ASI kurang hampir mencapai 50\%. Demikian juga di 2 wilayah puskesmas kecamatan di DKI Jakarta yaitu Kecamatan Tanjung Priok dan Kecamatan Cilandak, prevalensi PKA mencapai $32,0 \%$ dan $37,0 \%$. Berdasarkan ketiga studi terlihat bahwa di semua lokasi PKA secara konsisten menjadi penyebab kegagalan ibu 
Tabel 3. Kenaikan Berat Badan Ibu di 3 Studi Tahun 2010-2011

\begin{tabular}{|c|c|c|c|c|c|c|}
\hline \multirow{3}{*}{ Kenaikan Berat Badan Hamil } & \multicolumn{6}{|c|}{ Wilayah Puskesmas } \\
\hline & \multicolumn{2}{|c|}{ Kabupaten Karawang } & \multicolumn{2}{|c|}{ Kecamatan Tanjung Priok } & \multicolumn{2}{|c|}{ Kecamatan Cilandak } \\
\hline & n & $\%$ & $\mathbf{n}$ & $\%$ & n & $\%$ \\
\hline Tidak sesuai & 33 & 37,9 & 41 & 44,6 & 33 & 33,0 \\
\hline Sesuai & 54 & 62,1 & 51 & 55,4 & 67 & 67,0 \\
\hline Total & 100,0 & 100,0 & 92 & 100,0 & 100,0 & 100,0 \\
\hline
\end{tabular}

Tabel 4. Hubungan Kenaikan Berat Badan Hamil dan PKA di 3 Studi Tahun 2010-2011

\begin{tabular}{|c|c|c|c|c|c|}
\hline \multirow{2}{*}{ Wilayah Puskesmas } & \multirow{2}{*}{ Kenaikan Berat Badan Hamil } & \multicolumn{2}{|c|}{ PKA (\%) } & \multirow{2}{*}{ Nilai $p$} & \multirow{2}{*}{ OR $(95 \% \mathrm{CI})$} \\
\hline & & Tidak Cukup & Cukup & & \\
\hline \multirow[t]{2}{*}{ Kabupaten Karawang } & Tidak sesuai & 60,6 & 39,4 & 0,009 & 3,7 \\
\hline & Sesuai & 29,6 & 70,4 & & $(1,5-9,1)$ \\
\hline \multirow[t]{2}{*}{ Kecamatan Tanjung Priok } & Tidak sesuai & 48,8 & 51,2 & 0,006 & 3,9 \\
\hline & Sesuai & 19,6 & 80,4 & & $(1,6-9,8)$ \\
\hline \multirow[t]{2}{*}{ Kecamatan Cilandak } & Tidak sesuai & 60,6 & 39,4 & 0,001 & 4,5 \\
\hline & Sesuai & 25,4 & 74,6 & & $(1,9-11,0)$ \\
\hline
\end{tabular}

menyusui ASI eksklusif dengan rata-rata prevelensi sebesar $36,8 \%$.

Prevalensi jumlah ibu dengan kenaikan BB selama hamil tidak sesuai dengan rekomendasi IOM juga tergolong tinggi meliputi $37,9 \%$ di wilayah puskesmas Pelayanan Obstetri Neonatal Emergensi Dasar (PONED) Kabupaten Karawang, 44,6\% di wilayah puskesmas Kecamatan Tanjung Priok, dan 33,0\% di Kecamatan Cilandak. ${ }^{13}$ Ketidaksesuaian kenaikan berat badan selama hamil merupakan indikator status gizi ibu hamil yang penting karena berhubungan erat dengan dampak kehamilan baik pada bayi dan ibu. Kenaikan berat badan selama hamil juga merefleksikan status gizi ibu prahamil dan merupakan faktor prediksi status gizi ibu laktasi. Secara keseluruhan, status gizi maternal meliputi status gizi prahamil, status gizi ibu hamil, dan status gizi ibu laktasi adalah faktor penting yang memengaruhi keberhasilan ibu menyusui eksklusif selama 6 bulan.

Selama ini ada anggapan bahwa semua ibu hamil mampu memberikan ASI eksklusif selama 6 bulan terlepas dari status gizi ibu sehingga jika ada ibu yang dalam kenyataannya tidak mampu memberikan ASI eksklusif 6 bulan maka penyebabnya selalu diarahkan pada aspek pengetahuan, psikologis, dan perspektif dibandingkan aspek fisio-biologis. Namun pada manusia, kedua ranah tersebut diketahui memiliki hubungan yang erat, keadaan fisio-biologis dan keadaan psiko-emosional saling memengaruhi. Untuk itu, dilakukan analisis untuk melihat hubungan antara aspek fisio-biologis yang diukur melalui status gizi ibu hamil dan aspek psiko-emosional yang diukur melalui PKA.

Hasil analisis bivariat menunjukkan bahwa di wilayah puskesmas PONED Kabupaten Karawang terdapat sebanyak $60,6 \%$ ibu dengan kenaikan BB tidak sesuai rekomendasi yang mengalami PKA. Hasil uji statistik diperoleh nilai $\mathrm{p}=0,009$ dan $95 \% \mathrm{CI}=1,5-9,1$, yang berarti bahwa secara statistik ada hubungan bermakna antara kenaikan BB yang tidak sesuai dengan rekomendasi dan PKA. Diperoleh nilai odds ratio $(\mathrm{OR})=3,7$ yang artinya ibu dengan kenaikan BB yang tidak sesuai rekomendasi mempunyai peluang 3,7 kali lebih besar untuk mengalami PKA.

Di 2 wilayah puskesmas di Jakarta yaitu Kecamatan Tanjung Priok dan Kecamatan Cilandak juga menunjukkan hubungan signifikan antara kesesuaian kenaikan BB dan PKA dengan parameter statistik masing-masing nilai $\mathrm{p}=0,006$ dan 0,$001 ; 95 \% \mathrm{CI}=1,6-9,8$ dan $1,9-$ 11,0; OR = 3,9 dan 4,5. Di Kecamatan Tanjung Priok, ibu dengan kenaikan BB tidak sesuai rekomendasi memiliki peluang 3,9 kali lebih besar untuk mengalami PKA dan ibu dengan kenaikan BB tidak sesuai rekomendasi di Kecamatan Cilandak memiliki peluang 4,5 kali lebih besar untuk mengalami PKA. Ketiga studi secara konsisten dan meyakinkan menunjukkan bahwa status gizi ibu hamil yang diukur melalui kesesuaian kenaikan BB ibu selama hamil dan PKA memiliki hubungan yang erat dan bermakna. Hasil ketiga studi telah membuktikan adanya keterkaitan erat antara aspek fisio-biologis dengan aspek psiko-emosional pada ibu hamil dan menyusui. Hasil ini memiliki implikasi penting bagi program promosi ASI 
eksklusif 6 bulan yang saat ini mengalami stagnasi.

Penelitian Getahun et al, ${ }^{17}$ menunjukkan hasil yang tidak berbeda dengan penelitian ini yaitu ibu yang kurang gizi (IMT < 18,5) memberikan makanan tambahan kepada bayinya yang kurang gizi $(<-2 z$-score $)$ lebih cepat yaitu sebelum bayi berusia 6 bulan dibandingkan dengan ibu yang memberikan ASI eksklusif atau hampir eksklusif. Faktor utama ibu tersebut memberikan makanan tambahan kepada bayinya sebelum berusia 6 bulan karena PKA. Selanjutnya, Gatti, ${ }^{9}$ juga telah menyebutkan bahwa PKA merupakan faktor utama terjadinya kegagalan ASI pada ibu-ibu di dunia.

Penelitian kohort Kac et al, ${ }^{18}$ di Brazil membuktikan bahwa post partum weight retention lebih banyak berkurang pada ibu dengan persen lemak yang rendah dibandingkan dengan persen lemak yang tinggi yaitu $3 \mathrm{~kg}$ pada persen lemak $18 \%$ dan $0,04 \mathrm{~kg}$ pada ibu dengan persen lemak $35 \%$. Hal ini menunjukkan penggunaan energi ibu untuk memproduksi ASI. Bahkan terlihat ibu dengan status gizi kurang memerlukan lebih banyak energi untuk tetap dapat menyusui. Diduga pada tahapan status gizi ibu tidak dapat lagi mendukung proses pembentukan ASI tersebut, itu akan memilih memberikan makanan tambahan kepada bayinya. Sementara itu di Indonesia, prevalensi ibu muda kurang gizi yang ditandai dengan IMT rendah masih cukup tinggi yaitu sebesar $12,3 \%$ menurut data Riskesdas tahun 2010,3 sekitar $20 \%$ menurut de Pee et al, ${ }^{11}$ di daerah kumuh perkotaan, dan sekitar 9\% - 21\% menurut Irawati, 12 di daerah pedesaan.

Salah satu implikasi penting kajian ini adalah memberikan bukti ilmiah mengenai kekeliruan persepsi di kalangan pakar dan ahli gizi mengenai kemampuan ibu memberikan ASI eksklusif 6 bulan pada bayinya. Jika selama ini dipersepsikan bahwa semua ibu mampu memberikan ASI eksklusif selama 6 bulan pada bayinya maka hasil kajian ini menunjukkan bahwa ibu yang memiliki status gizi kehamilan yang baik memiliki peluang lebih besar untuk mampu memberikan ASI eksklusif selama 6 bulan karena tidak memiliki PKA. Dengan demikian, perhatian lebih besar seharusnya diberikan pada aspek status gizi maternal, baik status gizi pra hamil, status gizi kehamilan, dan status gizi laktasi karena tanpa status gizi maternal yang baik ibu akan mudah memiliki PKA yang pada gilirannya secara fisiologis menghambat produksi ASI dan menyebabkan kegagalan menyusui eksklusif 6 bulan.

\section{Kesimpulan}

Prevalensi PKA pada ibu hamil di 3 wilayah studi cukup tinggi yaitu rata-rata $36,8 \%$. Ditemukan hubungan yang erat dan bermakna antara status gizi ibu hamil dengan PKA, nilai OR berkisar pada 3,7 - 4,5 yang berarti bahwa ibu yang kenaikan BB selama hamil di bawah rekomendasi memiliki peluang 3,7 - 4,5 kali lebih besar untuk memiliki PKA dibandingkan ibu yang kenaikan BB selama hamil sesuai rekomendasi.

\section{Saran}

Persepsi bahwa semua ibu tanpa memperhatikan status gizi mampu menyusui eksklusif selama 6 bulan perlu diluruskan karena ibu yang status gizi kehamilannya baik memiliki peluang lebih besar untuk terhindar dari PKA sehingga memiliki peluang untuk berhasil menyusui secara ekskusif 6 bulan lebih besar pula. Aspek status gizi maternal meliputi status gizi prahamil, status gizi kehamilan, dan status gizi laktasi perlu mendapatkan perhatian khusus yang lebih besar jika ingin meningkatkan prevalensi ASI eksklusif 6 bulan.

\section{Daftar Pustaka}

1. World Health Organization. Infant and young child feeding. Model chapter for textbooks for medical students and allied health professionals. Geneva: World Health Organization; 2009.

2. World Health Organization. Report of the expert consultation on the optimal duration of exclusive breastfeeding. Geneva: World Health Organization; 2002.

3. Kementerian Kesehatan Republik Indonesia. Riset kesehatan dasar. Laporan Nasional 2010. Jakarta: Kementerian Kesehatan Republik Indonesia; 2010.

4. Badan Pusat Statistik. Survei demografi dan kesehatan Indonesia tahun 2007. Jakarta: Badan Pusat Statistik; 2007.

5. Syafiq A, Fikawati S. Laporan akhir ASUH baseline survey 2002 Provinsi Jawa Barat. Depok: Center for Family Welfare-University of Indonesia; 2003.

6. Syafiq A, Fikawati S. Mercy corps healthy start baseline survey North Jakarta, Indonesia, final report. Depok: Center For Health Research University of Indonesia-Mercy Corps Indonesia; 2007.

7. Tjekyan SRM. Pemberian ASI eksklusif pada bayi di beberapa puskesmas di Kota Palembang. Jakarta: Kementerian Pemberdayaan Perempuan dan Perlindungan Anak Republik Indonesia; 2003 [diakses tanggal 14 Februari 2010]. Diunduh dari:http://www.menegpp.go.id.

8. Chan SM, Nelson EA, Leung SS, Li CY. Breastfeeding failure in longitudinal post partum maternal nutritional in Hongkong. Journal of Paediatrics and Child Health. 2000; 36 (5): 466-71.

9. Gatti L. Maternal perceptions of insufficient milk supply in breastfeeding. Journal of Nursing Scholarship. 2008; 40 (4): 355-63.

10. Notoatmodjo S. Promosi kesehatan teori dan aplikasi. Jakarta: PT Rineka Cipta; 2005.

11. de Pee S, Diekhans J, Stallkamp G, Kiess L, Moench-Pfanner R, Martini $\mathrm{E}$, et al. Breastfeeding and complementary feeding practices in Indonesia. Nutrition and Health Surveillance System Annual Report 2002. Jakarta: Helen Keller Worldwide; 2002.

12. Irawati A, Triwinarto A, Salimar, Raswanti I. Pengaruh status gizi ibu selama kehamilan dan menyusui terhadap keberhasilan pemberian ASI. Jurnal Penelitian Gizi dan Makanan. 2003; 26 (2): 10-9.

13. Institute of Medicine. Weight gain during pregnancy: reexamining the guidelines. Washington DC: The National Academy Press; 2009. 
14. Trisnawati I. Hubungan status gizi ibu selama hamil dengan persepsi kemampuan laktasi di wilayah puskesmas PONED Kabupaten Karawang tahun 2010 [tesis]. Depok: Fakultas Kesehatan Masyarakat Universitas Indonesia; 2010.

15. Panjaitan M. Status gizi ibu selama hamil dan persepsi ketidakcukupan ASI di wilayah puskesmas Kecamatan Tanjung Priok Jakarta Utara tahun 2011 [skripsi]. Depok: Fakultas Kesehatan Masyarakat Universitas Indonesia; 2011.

16. Sari AP. Status gizi ibu selama hamil dan persepsi ketidakcukupan ASI di wilayah puskesmas Kecamatan Cilandak Jakarta Selatan tahun 2011 [skripsi]. Depok: Fakultas Kesehatan Masyarakat Universitas Indonesia; 2011.

17. Getahun Z, Scherbaum V, Taffese Y, Teshome B, Biesalski HK. Breastfeeding in Tigray and Gonder, Ethiopia, with special reference to exclusive/almost exclusive breastfeeding beyond six months. Australian Breastfeeding Association. Breastfeeding Review. 2004; 12 (3): 8-16.

18. Kac G, Benicio MHDA, Velasquez-Melendes G, Valente JG, Struchiner CJ. Breastfeeding and postpartum weight retention in a cohort of Brazilian women. American Journal of Clinical Nutrition. 2004; 79: 487-93. 